\section{УПРАВЛІННЯ ВИТРАТАМИ СІЛЬСЬКОГОСПОААРСЬКОГО ПІДПРИЕМСТВА В КОНТЕКСТІ ВПЛИВУ ОПЕРАЦІЙНОГО ВАЖЕЛЯ $\odot$}

В.В. МАКОГОН, кандидат економічних наук, доцент

О.В. ГОРОХ, кандидат економічних наук, доцент, Харківський національний аграрний університет ім. В.В. Докучаєва

(Харків)

Досліджено вплив на прибутковість і ризикованість виробництва окремих видів сільськогосподарської продукиії ефекту операційного важеля. Встановлено, щуо чим сильнішими є коливання цін на соняшник та інші види сільськогосподарської продукції, тим потужнішим, за інших рівних умов, є їх впалив на формування фінансового результату галузей із вищьюю капіталомісткістю виробництва $i$ більшою часткою постійних витрат у загальному обсязі виробничих витрат. У свою чергу, краще інфраструктурне забезпечення ринку насіння соняиника, застосування форвардних операчій дозволяє нівелювати негативний мультиплікативний вплив ефекту операційного важеля на формування фінансових результатів ичієї галузі. Це визначає необхідність пришвидшення розвитку інфраструктури сегментів аграрного ринку мало придатних для форвардних операиій.

Ключові слова: операційний важіль, управління витратами, рентабельність, ринкова інфраструктура, інвестиції, постійні витрати, амортизація

Табл.: 1. Рис.: 1. Літ.: 14.

\title{
MANAGEMENT OF THE EXPENSES OF AGRICULTURAL ENTERPRISE IN THE CONTEXT OF EXPOSURE TO THE OPERATIONAL ARM
}

\author{
MAKOGON Vitaliy, \\ Candidate of Economic Sciences, Associate Professor, \\ HOROKH Alexander, \\ Candidate of Economic Sciences, Associate Professor, \\ Kharkiv National Agrarian University named after V.V. Dokuchaev
} (Kharkiv)

It has been established that the stronger is the price fluctuations on the sunflower and other agricultural products, the more powerful is their influence on the formation of financial results of the industries with the high capital intensity of production and with a larger share of the fixed costs in the total production costs. In its turn the better infrastructure support for the sunflower seed market and the use of the forward operations allow to level the negative multiplicative effect of the operational leverage on the formation of the financial results of this industry. The latter determines the necessity to accelerate the

${ }^{(\subset) ~ В . В . ~ М А К О Г О Н, ~ О . В . ~ Г О Р О Х, ~} 2019$ 
development of the infrastructural segments of the agrarian market which are not suitable for the forward operations. The results of the study are used in developing the recommendations regarding the management of the agricultural enterprises expenses.

Key words: operational leverage, costs management, profitability, market infrastructure, capital investments, fixed costs, amortization.

Tabl.: 1. Fig.: 1. Ref.: 14.

\section{УПРАВЛЕНИЕ ЗАТРАТАМИ СЕЛЬСКОХОЗЯЙСТВЕННОГО ПРЕДПРИЯТИЯ В КОНТЕКСТЕ ВОЗДЕЙСТВИЯ ОПЕРАЦИОННОГО РЫЧАГА}

МАКОГОН В.В., кандидат экономических наук, доцент,

ГОРОХ А.В., кандидат экономических наук, доцент, Харьковский национальный аграрный университет им. В.В. Докучаева (2. Харьков)

Исследовано влияние на прибыльность и рискованность производства отдельных видов сельскохозяйственной продукции эффекта операционного рычага. Установлено, что чем сильнее колебания цен на подсолнечник и другие виды сельскохозяйственной продукции, тем сильнее, при прочих равных условиях, они влияют на формирование финансового результата отраслей с высокой капиталоёмкостью производства и большей долей постоянных затрат в общем объеме производственных затрат. В свою очередь, лучшее инфраструктурное обеспечение рынка семян подсолнечника, применение форвардных операчий позволяет нивелировать негативное мультипликативное влияние эффекта операчионного рычага на формирование финансовых результатов этой отрасли. Последнее определяет необходимость ускорения развития инфраструктуры сегментов аграрного рынка мало пригодных для форвардных операџий. Результаты исследования используются при разработке рекомендаций относительно управления затратами сельскохозяйственных предприятий.

Ключевые слова: операционный рычаг, управление затратами, рентабельность, рыночная инфраструктура, инвестиции, постоянные затраты, амортизация.

Табл.: 1. Рис.: 1. Лит.: 14.

Постановка проблеми. Ефективне управління витратами у системі «обсяги витрати - прибуток» є нагальною проблемою для більшості сільськогосподарських підприємств України. Ринкова волатильність і нестійкість кон'юнктури на споживчому ринку рентабельності потребує чіткої систематизації підходів до прийняття рішень стосовно управління витратами i прибутком. Одним iз інструментів цього механізму $є$ операційний важіль (леверидж), дослідження практичних аспектів дії якого, а також можливостей його практичного застосування в управлінській практиці, зумовлює актуальність заявленої теми дослідження

Аналіз останніх досліджень і публікацій. Необхідність ефективного управління витратами підприємства є базовим підгрунтям для процесу підвищення конкурентоспроможності суб'єкту господарювання. Дефініції та концептуальним 


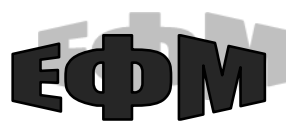

http://efm.vsau.org/

основам управління витратами підприємства присвячені роботи А. Аткінсона [8], Р. Купера [9], Р.С. Каплана [10], К. Шелла [11], М. Пека [12], М. Портера [13], Дж.К. Шанка та В. Говиндараджана [14] та ін. Серед українських вчених слід відзначити внесок, що зробили в своїх працях Л.В. Гнилицька [2], С.Ф. Голов [3], М.Г. Грещак [4], А.М. Турило [5], Г.В. Козаченко [6], А.В. Череп [7]. Разом 3 тим, поза увагою дослідників залишаються питання оптимізації співвідношення темпів приросту операційних і інвестиційних витрат, а також нейтралізації негативного впливу високого операційного важеля в умовах нестійкої ринкової кон'юнктури.

Формулювання цілей статті. Метою статті $є$ висвітлення особливостей управління витратами сільськогосподарського підприємства в контексті впливу операційного важеля.

Виклад основного матеріалу дослідження. Ознакою сьогодення $є$ динаміка виробництва i збуту олійних культур, у першу чергу насіння соняшника, що стабільно зростає. Так, якщо питома вага виручки від його продажу державі у 1990 p. складала лише одну десяту від iї значення для молока і одну п'ятнадцяту для м'яса, то у 2017 р. сукупні грошові надходження сільськогосподарських підприємств від продажу цих двох видів продукції не перевищували трьох четвертих виручки від реалізації ними насіння соняшника. При цьому, якщо у 1990 р. частка соняшника i кормових культур у структурі посівних площ дорівнювали 5,3 і 38,1\%, то у 2017 р. вона складала вже 25,6\% та 3,3\% відповідно.

Це $\epsilon$ наслідком втрачання економічного інтересу сільськогосподарських підприємств до виробництва інших видів продукції, наприклад, цукрових буряків, що було зумовлено нижчою рентабельністю бурякової галузі і вищою волатильністю іiі фінансових результатів. Так, якщо середня рентабельність продажу насіння соняшника у 2005-2017 рр. дорівнювала 46,0\%, то для цукрових буряків вона була нижчою на 30,4 в.П. При цьому коефіцієнт варіації від середнього значення рентабельності для соняшника дорівнював 43,3\%, а для цукрового буряка $-84,0 \%$.

Ще однією вадою буряківництва, порівняно із олійними культурами, є вища капіталомісткість виробництва. Це призводить до вищої частки постійних витрат, зокрема амортизації, у структурі витрат на їх виробництво. Наслідком цього є вище значення операційного важеля, що в умовах нестійкої кон'юнктури мультиплікативним чином підвищує ризикованість інвестування коштів у розвиток галузі. Хоча слід одразу зауважити, що вище значення операційного важеля для буряківництва $є$ лише компонентом сукупного підприємницького ризику. Основними факторами, що підвищують його, є непостійність та невизначеність обсягу продажу та витрат виробництва. Операційний важіль збільшує вплив цих факторів на варіацію прибутку, проте не він є її першоджерелом [1, с. 381].

Підтвердження цього припущення грунтується на оцінці впливу операційного важеля на динаміку фінансово-економічних результатів функціонування окремих галузей $з$ урахуванням напряму змін цих показників у динаміці. При цьому 3 урахуванням недосконалості інформаційного забезпечення аналізу для часткової оцінки операційного важеля виробництва насіння соняшника i коренеплодів цукрових буряків були використані значення амортизаційних відрахувань. Було встановлено, що витрати на амортизацію у буряковій галузі вітчизняних сільськогосподарських підприємств на одиницю зібраної площі у 2017 p. перевищували аналогічні показники для виробництва зерна пшениці і насіння соняшника у 2,35 і 2,27 разу відповідно. 
Надалі було оцінено вплив ефекту операційного важеля на показники виробництва i збуту насіння соняшника i цукрових буряків вітчизняними сільськогосподарськими підприємствами у 2011-2013 pp., у які динаміка їх прибутковості була синхронно спадною. Зокрема було визначено масу прибутку на одиницю їх зібраної площі, виходячи, як з фактичної повної собівартості реалізованої продукції соняшникової і бурякової галузі, так і з аналогічних показників при повній собівартості, зменшеній на величину амортизації (табл. 1).

Таблиия 1

Оцінка ефекту операційного важеля у динаміці прибутку від реалізації насіння соняшника і цукрових буряків сільськогосподарськими підприсмствам України у 2011-2013 рр.

\begin{tabular}{|c|c|c|c|c|c|c|}
\hline \multirow{2}{*}{ Показники } & \multicolumn{3}{|c|}{ Насіння соняшника } & \multicolumn{3}{|c|}{ Цукровий буряк } \\
\hline & 2011 p. & 2012 p. & 2013 p. & 2011 p. & 2012 p. & 2013 p. \\
\hline Зібрана площа, тис. га & 3827 & 4107 & 4137 & 462 & 400 & 217 \\
\hline Валовий збір, тис. тонн & 6219 & 6178 & 8186 & 16263 & 16039 & 8764 \\
\hline $\begin{array}{l}\text { Обсяг реалізованої продукції, } \\
\text { тис. тонн }\end{array}$ & 5024 & 6813 & 6957 & 6844 & 6388 & 3044 \\
\hline $\begin{array}{l}\text { У розрахунку на } 1 \text { га зібраної } \\
\text { площі, грн } \\
\text { виробничі витрати }\end{array}$ & 2705,0 & 3362,8 & 3826,7 & $\begin{array}{r}11 \\
239,5\end{array}$ & $\begin{array}{r}13 \\
574,7\end{array}$ & 13650,3 \\
\hline амортизація & 162,6 & 198,7 & 232,1 & 417,1 & 457,0 & 674,3 \\
\hline $\begin{array}{l}\text { Частка амортизації у структурі } \\
\text { витрат, \% }\end{array}$ & 6,0 & 5,9 & 6,1 & 3,7 & 3,4 & 4,9 \\
\hline $\begin{array}{l}\text { Собівартість тонни реалізованої } \\
\text { продукції, грн } \\
\text { виробнича }\end{array}$ & 1664,9 & 2235,3 & 1933,8 & 319,5 & 338,8 & 338,0 \\
\hline повна & 2054,4 & 2463,2 & 2320,5 & 380,4 & 371,5 & 388,9 \\
\hline без урахування амортизації & 1930,9 & 2317,6 & 2179,8 & 366,3 & 359,0 & 369,7 \\
\hline $\begin{array}{l}\text { Ціна тонни реалізованої } \\
\text { продукції, грн }\end{array}$ & 3224,9 & 3590,9 & 2982,1 & 519,2 & 430,0 & 399,6 \\
\hline $\begin{array}{l}\text { Прибуток на } 1 \text { га зібраної } \\
\text { площі, грн } \\
\text { фактичний }\end{array}$ & 1536,2 & 1870,9 & 1112,7 & 2054,4 & 933,3 & 149,3 \\
\hline без урахування амортизації & 1698,3 & 2112,4 & 1349,4 & 2263,4 & 1132,8 & 418,7 \\
\hline $\begin{array}{l}\text { Індекси зміни прибутку на } 1 \text { га } \\
\text { зібраної площі, \% } \\
\text { фактичного }\end{array}$ & 100,0 & 121,8 & 72,4 & 100,0 & 45,4 & 7,3 \\
\hline без урахування амортизації & 100,0 & 124,4 & 79,5 & 100,0 & 50,0 & 18,5 \\
\hline $\begin{array}{l}\text { Темп зміни прибутку на } 1 \text { га } \\
\text { зібраної площі, \% } \\
\text { фактичного }\end{array}$ & & $-13,8$ & & & $-46,4$ & \\
\hline без урахування амортизації & & $-10,3$ & & & $-40,7$ & \\
\hline Ефект операційного важеля, \% & & 3,5 & & & 5,7 & \\
\hline
\end{tabular}

Джерело: розраховано авторами на підставі даних офіџійного сайту Державної служби статистики Украӥни, http://www.ukrstat.gov.ua 
При цьому відсоток амортизації у повній собівартості реалізованої продукції було прийнято на рівні іï частки у сукупних виробничих витратах на виробництво кожної з культур у відповідному році. Так повну собівартість насіння соняшника без урахування частки амортизації, яка у 2011 р. дорівнювала 1930,9 грн/тонну, було визначено шляхом зменшення повної собівартості на частку амортизації у витратах на його виробництво у цей рік $(1930,9=2054,4 *(100,0-6,0) / 100)$. Надалі, задля забезпечення співставності даних, динамічні ряди питомих значень фактичного і скоригованого на величину амортизації прибутку у 2011-2013 рр. було трансформовано у індексні ряди, що дозволило визначити середній темп їх змін.

При цьому точкою відліку для обчислення базисних індексів маси прибутку на одиницю посівів було обрано відповідні дані по обох культурах за 2011 р. 3 урахуванням цих розрахунків встановлено, що маса прибутку на гектар зібраних сільськогосподарськими підприємствами України площ соняшника у 2011-2013 рр. щорічно скорочувалася на 13,8\%. Натомість по цукрових буряках вона знижувалася, відповідно, на 46,4\%. У той же час, показники виходу прибутку на гектар зібраних ними площ соняшника і цукрових буряків, обчисленого без урахування амортизації, у досліджуваному періоді щорічно зменшувалася на 13,8 і 40,7\% відповідно.

Це дозволило оцінити ефект операційного важеля, зумовленого величиною і часткою постійних витрат акумульованих у амортизаційних відрахуваннях. Так їх включення до маси витрат, перенесених на реалізаційну собівартість насіння соняшника, зумовлювало пришвидшення темпів скорочення погектарної величини прибутку на 3,5\%. У той же час, для цукрового буряка негативний ефект операційного важеля дорівнював 5,7\%. Отже, слід констатувати сильніший негативний вплив операційного важеля на окупність витрат у буряковій галузі.

Утім не можна сказати, що операційний важіль не чинив мультиплікативного впливу на динаміку показників ефективності виробництва соняшника. Його наявність об'єктивно зумовлена характером впливу частки постійних витрат на окупність змінних. Але при цьому, за умов спадної динаміки цін на насіння соняшника, краща якість інфраструктури цього сегменту аграрного ринку компенсувала операційні ризики, зумовлені недоліками у формуванні структури витрат. Так волатильність окупності витрат, яка $є$ наслідком іiї циклічних коливань, притаманна для більшості видів продукції рослинництва. На підтвердження цього було досліджено динаміку окупності витрат на виробництва насіння соняшника, цін на нього та собівартості одиниці цього виду продукції у сільськогосподарських підприємствах України у 2005-2017 рр. (рис. 1).

Встановлено, що найбільш суттєве зниження цін на насіння сояшника мало місце у 2012-2013 рр. Наслідком цього стало зниження як окупності витрат на виробництва цього виду продукції, так і реактивне уповільнення темпів приросту питомих витрат на його виробництво у 2013-2014 рр. Це дозволило у ці роки собівартості одиниці продукції не перевищити рівня 2012 р. При цьому слід звернути увагу на наступне: коефіцієнт парної кореляції між ціною на насіння соняшника i окупністю витрат на його виробництво, що дорівнював 0,5101, вказує на вагомість цінового фактору у формуванні фінансових результатів галузі. 


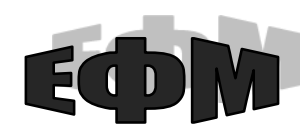

http://efm.vsau.org/

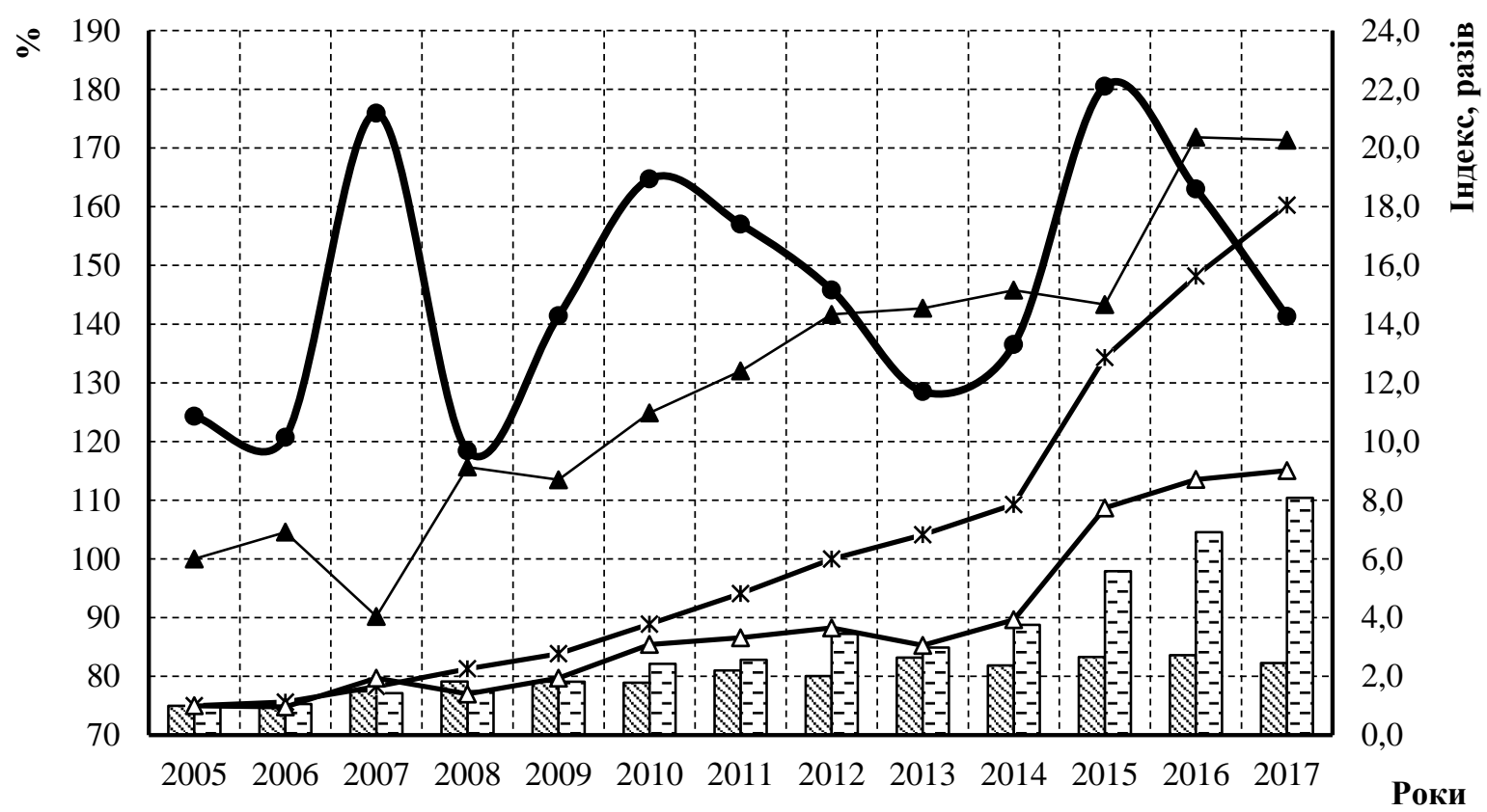

ॠ Індекс урожайності, разів

—-- Індекс виробничої собівартості одиниці продукції, разів

$\longrightarrow$ Окупність витрат, \%

- - Індекс посівних площ, \%

-ж-Індекс питомих витрат на 1 га, разів

$\rightarrow-$ Індекс цін, разів

Рис. 1. Тенденції змін витратних і результативних показників

функціонування соняшникової галузі сільськогосподарських підприємств України у 2005-2017 pp.

Джерело: складено автором на підставі даних офіщійного Державної служби статистики України, http://www.ukrstat.gov.ua

Натомість значення парного коефіцієнта кореляції між ціною у минулому році і питомими виробничими витратами поточного, що дорівнювало 0,9533 , вказує на високий рівень розвитку інфраструктури ринку насіння соняшнику, яка ефективно регулює поведінку виробника за рахунок надання інформації про ринкову кон'юнктуру.

Висновки. Зростання фінансових результатів соняшникової галузі на фоні стагнації інших стало можливим за умов формування адекватної ринковій кон'юнктурі структури витрат. При цьому, чим сильнішими є коливання цін на соняшник та інші виді сільськогосподарської продукції, тим потужнішим, за інших рівних умов, $є$ їх впалив на формування фінансового результату галузей із вищою капіталомісткістю виробництва і більшою часткою постійних витрат у загальному обсязі виробничих витрат. У свою чергу, краще інфраструктурне забезпечення ринку насіння соняшника, застосування форвардних операцій дозволяє нівелювати негативний мультиплікативний вплив ефекту операційного важеля на формування фінансових результатів цієї галузі, що визначає необхідність пришвидшення розвитку інфраструктури сегментів аграрного ринку мало придатних для форвардних операцій. 


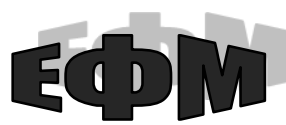

http://efm.vsau.org/

\section{Список використаних джерел}

1. Основы управления финансами / Дж.К. Ван Хорн; гл. ред. Я.В. Соколов. Москва: Финансы и статистика, 2005. 800 с.

2. Гнилицька Л.В. Обліково-аналітичне забезпечення економічної безпеки підприємства: монографія. Київ: КНЕУ, 2012. 305 с.

3. Голов С.Ф., Єфіменко В.І. Фінансовий та управлінський облік. Київ: ТОВ «Автоінтерсервіс», 1996. 544 с.

4. Грещак М.Г., Коцюба О.С. Управління витратами. Київ.: КНЕУ, 2002. 131 с.

5. Турило А.М., Кравчук Ю.Б., Турило А.А. Управління витратами підприємства. Київ: Центр навчальної літератури, 2006. 120 с.

6. Управління затратами підприємства: монографія / Козаченко Г.В., Погорєлов Ю.С., Хлапьонов Л.Ю., Макухін Г.А. Київ: Лібра, 2007. 320 с.

7. Череп А.В. Управління витратами суб'єктів господарювання: монографія. Харків: ІНЖЕК, 2007. 368 с.

8. Management Accounting: Information for Decision Making and Strategy Execution / Atkinson A., Anthony A., Kaplan R., Matsumura E., Mark S. New York: Pearson Education, 2011. 552 p.

9. Cooper R., Crawford C., Hustad T. Winning at New Products. Journal of Product Innovation Management. 1986. № 3. P. 307-308.

10. Kaplan R. The Evolution of Management Accounting. Accounting Review. 1984. Vol. 59., № 3. P. 390-418.

Journal of Monetary Economics, Elsevier. 2010. Vol. 57 (4). P. 420-427.

12. Peck M., Scherer F. The Weapons Acquisition Process: An Economic Analysis. Performance New York: Free Press, 1985. 557 p.

14. Shank J., Govindarajan V. Strategic Cost Management: The Value Chain Perspective. Journal of Management Accounting Research. 1992. № 4. P. 177-197.

\section{References}

1. Van Horn, J.K. (2005). Osnovy upravleniya finansami [Fundamentals of Financial Management] Moscow, Financy i Statistika, 800 [in Russian].

2. Hnylyts'ka, L.V. (2012). Oblikovo-analitychne zabezpechennya ekonomichnoyi bezpeky pidpryyemstva [Accounting and analytical support of economic safety of the enterprise] Kiev: KNEU, 305 [in Ukrainian].

3. Holov, S.F. \& Yefimenko, V.I. (1996). Finansovyy ta upravlins'kyy oblik [Financial and managerial accounting]. Kyiv, TOV «Avtointerservis», 544 [in Ukrainian].

4. Hreshchak, M.H. \& Kotsyuba, O.S. (2002). Upravlinnya vytratamy [Cost management]. Kyiv, KNEU, 131 [in Ukrainian].

5. Turylo, A.M., Kravchuk, Yu.B. \& Turylo, A.A. (2006). Upravlinnya vytratamy pidpryyemstva [Management of enterprise expenses]. Kyiv, Tsentr navchal'noyi literatury, 120 [in Ukrainian].

6. Kozachenko, H.V., Pohoryelov, Yu.S., Khlap'onov, L.Yu. \& Makukhin H.A. (2007). Upravlinnya zatratamy pidpryyemstva [Cost management of the enterprise]. Kyiv, Libra, 320 [in Ukrainian].

7. Cherep, A.V. (2007). Upravlinnya vytratamy sub"yektiv hospodaryuvannya [Management of expenses of business entities]. Kharkiv, INZHEK, 368 [in Ukrainian]. 
8. Atkinson, A., Anthony, A., Kaplan, R., Matsumura, E. \& Mark, S. (2011). Management Accounting: Information for Decision Making and Strategy Execution. New York: Pearson Education, 552.

9. Cooper, R., Crawford, C. \& Hustad, T. Winning at New Products. Journal of Product Innovation Management, 1986, 3, 307-308.

10. Kaplan, R. The Evolution of Management Accounting. Accounting Review, 1984, 59 (3), 390-418.

11. Peck, J. \& Shell, K. Could making banks hold only liquid assets induce bank runs? Journal of Monetary Economics, Elsevier, 2010, 57 (4), 420-427.

12. Peck, M. \& Scherer, F. (1984). The Weapons Acquisition Process: An Economic Analysis. Retrived from http://www.cert.org/archive/pdf/peck.pdf.

13. Porter, M.E. (1985). Competitive Advantage: Creating and Sustaining Superior Performance. New York: Free Press.

14. Shank, J. \& Govindarajan V. Strategic Cost Management: The Value Chain Perspective. Journal of Management Accounting Research, 1992, 4, 177-197.

\section{Відомості про авторів}

МАКОГОН Віталій Вікторович - кандидат економічних наук, доцент, посада - доцент кафедри фінансів Харківського національного аграрного університету ім. В.В. Докучаєва 62483, Харківська область, Харківський район, п/в «Докучаєвське 2»witmak.ua@gmail.com.

ГОРОХ Олександр Володимирович - кандидат економічних наук, доцент, посада - декан факультету обліку і фінансів, доцент кафедри фінансів Харківського національного аграрного університету ім. В.В. Докучаєва 62483, Харківська область, Харківський район, п/в «Докучаєвське - 2» gorohsasha82@gmail.com.

MAKOGON Vitaliy Viktorovich, Ph.D., associate professor, Position - Associate Professor, Department of Finance, Kharkiv National Agrarian University. V.V. Dokuchaeva 62483, Kharkiv region, Kharkiv district, p / o "Dokuchaevskoe - 2" witmak.ua@gmail.com.

GOROH Alexander Vladimirovich, Candidate of Economic Sciences, Associate Professor, Position - Dean of the Faculty of Accounting and Finance, Associate Professor of Finance, Kharkiv National Agrarian University. V.V. Dokuchaeva 62483, Kharkiv region, Kharkiv district, p / o "Dokuchaevskoe - 2" gorohsasha82@ gmail.com.

МАКОГОН Виталий Викторович, кандидат экономических наук, доцент, должность - доцент кафедры финансов Харьковского национального аграрного университета им. В.В. Докучаева 62483, Харьковская область, Харьковский район, п/о «Докучаевское - 2» witmak.ua@gmail.com.

ГОРОХ Александр Владимирович, кандидат экономических наук, доцент, должность - декан факультета учета и финансов, доцент кафедры финансов Харьковского национального аграрного университета им. В.В. Докучаева 62483, Харьковская область, Харьковский район, п/о «Докучаевское - 2» gorohsasha82@gmail.com. 